\title{
Migration of pollutants in porous soil environment
}

\author{
Kazimierz Szymański, Beata Janowska* \\ Koszalin University of Technology, Poland \\ Faculty of Civil Engineering, Environmental and Geodetic Science, Department Waste Management \\ *Corresponding author's e-mail: beata.janowska@tu.koszalin.pl
}

Keywords: migration, landfill leachates, water pollution, linear multiple regression functions.

\begin{abstract}
Landfill leachate makes a potential source of ground water pollution. Municipal waste landfill substratum can be used for removal of pollutants from leachate. Model research was performed with use of a sand bed and artificially prepared leachates. Effectiveness of filtration in a bed of specific thickness was assessed based on the total solids content. Result of the model research indicated that the mass of pollutants contained in leachate filtered by a layer of porous soil $\left(m_{f}\right)$ depends on the mass of pollutants supplied $\left(m_{d}\right)$. Determined regression functions indicate agreement with empirical values of variable $m_{f}^{\prime}$. The determined regression functions allow for qualitative and quantitative assessment of influence of the analysed independent variables $\left(m_{d}{ }_{d}, l, \omega\right)$ on values of mass of pollutants flowing from the medium sand layer. Results of this research can be used to forecast the level of pollution of soil and underground waters lying in the zone of potential impact of municipal waste landfill.
\end{abstract}

\section{Introduction}

Pollutants contained in leachates generated in landfill sites can result from impact of variable factors including biological (bacteria, viruses, higher organisms), chemical (dissolved solids, liquid, gaseous and radioactive substances), physical (heat exchange, leaching, evaporation) (Islam and Singhal 2004, Lagaly et al. 2006, Suchowska-Kisielewicz and Jędrczak 2008). Movement of pollutants in porous natural soil environment is accompanied by processes of sorption and desorption, ion exchange, colmatation and filtration. These determine purifying properties of a given medium (Cook et al. 2005, Kjeldsen et al. 2002, Ghosh et al. 2013, Lacerda et al. 2014, Zhan et al. 2014). It has been found that biological pollutants are degraded mainly in the aeration zone (Bedient et al. 1983). Unfortunately, remaining pollutants contained in leachates that migrate to underground water saturation zone cause not just water pollution but may also migrate considerable distance, often many kilometres ( $\mathrm{Li}$ et al. 2012, Szymański and Siebielska 2000, Szymański et al. 2007, Reyes-López et al. 2008, Szymański and Nowak 2012).

An attempt was made in this work to estimate the masses of pollutants flowing from the aeration zone (e.g. soil substratum under municipal waste landfill) to the saturation zone (underground waters) (Schiopu and Gavrilescu 2010). Biochemical decomposition of organic compounds in waste deposited in municipal landfills has been observed already at the beginning of landfilling (den Boer et al. 2010, Pieczykolan et al. 2013, Reyes-López et al. 2008, Suchowska-Kisielewicz and Jędrczak 2008). In aerobic conditions mostly carbon dioxide and water are generated and in anaerobic decomposition - methane and water. Such decomposition is caused by microorganisms that activate themselves at specific temperature, humidity and in presence of nutrients (Janowska and Szymański 2009, Siebielska 2014, Siebielska and Sidełko 2015). Depending on oxygen conditions that occur in landfill, aerobic or anaerobic bacteria prevail (Kjeldsen et al. 2002, Renou et al. 2008).

Migration of pollutants in soil substratum, both in the aeration and saturation zones has been a theme of many research works (Koda et al. 2009, Regadio et al. 2012, Zhan et al. 2014, Melnyk et al. 2014). Nevertheless, it should be pointed out that until now, despite implementation of more and more perfect numerical models, solution of this issue is still considered insufficient. The migration process analysis is limited mostly to convectional movement of pollutants taking into account in calculations diffusion movement (molecular diffusion and hydrodynamic dispersion) for various variants of the hydrodynamic field. Introduction of biochemical, physical and chemical factors to the analysis makes the solutions so complicated that they often are unfit for practical application (Koda et al. 2009, Thornton et al. 2000, Rosqvist and Destouni 2000, Nayak et al. 2007, Varank et al. 2011, Li et al. 2012).

Due to interaction of phenomena that occur during leachate flow in soil, it was considered appropriate to develop an approximate method of estimation of soil purification properties. The method is based on experimental tests that reflect real soil conditions. They allow for evaluation of purification effectiveness of specific leachate group in the aeration zone (Renou et al. 2008, Wisznowski et al. 2006, Varank et al. 2011). 


\section{Material and methods}

Model research reflecting infiltration of leachate through the aeration zone was performed in order to define the qualitative and quantitative association between mass of the pollutants supplied and discharged from the porous medium. Filtration columns were filled with medium sand and artificially made leachates. The physical and chemical composition of the leachates was selected to appropriately reflect the contents of chosen indicators in real leachates (see Table 1) (Szymański and Nowak 2012). Variable parameters in those tests were: intensity of supplied leachate $\omega$ (volume of leachate per unit of area and time), mass of supplied pollutants $m_{d}$ and soil thickness $l$. Change of the mass of pollutants filtered through the model layer $m_{f}$ depending on those parameters, was analysed for the total solids (Castrillon et al. 2010, Renou et al. 2008, Liu et al. 2010).

Tests were performed in typical cylindrical filtration columns placed on an appropriately constructed supporting structure. The columns were made of plastic material (plexi), with height of $1.0 \mathrm{~m}$ and diameter $0.1 \mathrm{~m}$. Nets supporting the bed were fitted and fixed at the base of each column. Both the bottom and top section of the column were isolated from the environment with a special polyethylene film hubcap. The porous medium layer (medium sand) filling up the column to a specified height, was formed by compaction of particular layers using a manually operated compactor. Particular sand layers in the columns were formed in identical way.

The landfill leachate prepared under laboratory conditions featured constant and reproducible chemical composition (leachate chemical composition is shown in Table 1) (Pieczykolan et al. 2013, Abdelaal et al. 2014).

In each case, a specified dose of leachate was supplied to the top surface of the filter bed. The leachate was supplied by a specially designed feeder that allowed for even leachate distribution over the bed surface. After a certain period of time, dependent on the filtration bed type, height and volume of leachate, the filtrate flowed out from the column's bottom section. During this experiment the outflow commencement time (counting from the moment of supply of the first leachate dose), filtrate volume and filter bed height were recorded. Leachate supplied to the column as well as the filtrate were chemically analysed (Renou et al. 2008, Thornton et al. 2000, Zhu et al. 2013).

Medium sand taken from the municipal waste landfill area was used for the tests. Its maximum and minimum density was $\left(\rho_{d}\right)_{\max }=1.79 \cdot 10^{3} \mathrm{~kg} / \mathrm{m}^{3},\left(\rho_{d}\right)_{\min }=1.63 \cdot 10^{3} \mathrm{~kg} / \mathrm{m}^{3}$ respectively, whereas its maximum density at the humidity in which the sand was used in the model research $(\mathrm{w}=2.3 \%)$ was $\rho_{\max }=1.83 \cdot 10^{3} \mathrm{~kg} / \mathrm{m}^{3}$. The column contained approx. $2.0 \mathrm{~kg}$ of sand, which was then compacted by $1.0 \mathrm{~kg}$ compactor dropped ten times from approx. $0.5 \mathrm{~m}$. Once the bed was formed up to a defined height its thickness was measured and density calculated ((Rosqvist and Destouni 2000, Thornton et al. 2000). Three series of tests were performed. Each test series differed in thickness, which was: $l_{1}=0.3 \mathrm{~m}, l_{2}=0.6 \mathrm{~m}, l_{3}=0.9 \mathrm{~m}$ respectively. In each series particular columns were supplied everyday with leachate with varied intensity: $\omega_{1}=0.026 \mathrm{~m}^{3} / \mathrm{m}^{2} \mathrm{~d}, \omega_{2}=0.052$ $\mathrm{m}^{3} / \mathrm{m}^{2} \mathrm{~d}, \omega_{3}=0.104 \mathrm{~m}^{3} / \mathrm{m}^{2} \mathrm{~d}\left(\omega_{2}=2 \cdot \omega_{1}, \omega_{3}=4 \cdot \omega_{1}\right)$. Therefore, for each series following volumes of leachate were supplied to the first filtration column: $v_{1}=195 \cdot 10^{-6} \mathrm{~m}^{3}$, to the second column: $v_{2}=390 \cdot 10^{-6} \mathrm{~m}^{3}$ and to the third: $v_{3}=780 \cdot 10^{-6} \mathrm{~m}^{3}$. During the entire test approximately fifty leachate doses were supplied to each column.

In leachates and filtrates COD (dichromate method), chlorides (argentometric method), ammonium nitrogen (Nessler's method), nitrates (V) (spectrophotometric method as per PN-82/C-04576/08 standard), nitrates (III)

Table 1. Composition of the leachate prepared for tests in laboratory conditions

\begin{tabular}{|c|c|c|}
\hline Component & Unit & Value \\
\hline $\mathrm{NaCl}$ & $g / m^{3}$ & 2040 \\
\hline $\mathrm{NH}_{4} \mathrm{NO}_{3}$ & $\mathrm{~g} / \mathrm{m}^{3}$ & 360 \\
\hline $\mathrm{NaNO}_{2}$ & $\mathrm{~g} / \mathrm{m}^{3}$ & 360 \\
\hline $\mathrm{FeCl}_{3} \cdot 6 \mathrm{H}_{2} \mathrm{O}$ & $\mathrm{g} / \mathrm{m}^{3}$ & 720 \\
\hline $\mathrm{FeCl}_{2} \cdot 4 \mathrm{H}_{2} \mathrm{O}$ & $g / m^{3}$ & 600 \\
\hline $\mathrm{KH}_{2} \mathrm{PO}_{4}$ & $\mathrm{~g} / \mathrm{m}^{3}$ & 120 \\
\hline $\mathrm{K}_{2} \mathrm{SO}_{4}$ & $\mathrm{~g} / \mathrm{m}^{3}$ & 240 \\
\hline Acetic acid & $\mathrm{dm}^{3} / \mathrm{m}^{3}$ & 12 \\
\hline L-Serine & $\mathrm{g} / \mathrm{m}^{3}$ & 120 \\
\hline DL-Valine & $g / m^{3}$ & 120 \\
\hline Saccharose & $g / m^{3}$ & 120 \\
\hline $\mathrm{Na}_{2} \mathrm{CO}_{3}$ & $\mathrm{~g} / \mathrm{m}^{3}$ & 120 \\
\hline $\mathrm{MgSO}_{4} \cdot 7 \mathrm{H}_{2} \mathrm{O}$ & $\mathrm{g} / \mathrm{m}^{3}$ & 1200 \\
\hline Ninhydrine & $\mathrm{g} / \mathrm{m}^{3}$ & 120 \\
\hline L-iso-Leucine & $\mathrm{g} / \mathrm{m}^{3}$ & 240 \\
\hline
\end{tabular}


(spectrophotometric method as per PN-73/C-04576/06 standard), total iron (AAS method) (see Table 2) were determined. Total solids were determined at $105^{\circ} \mathrm{C}$, whereas residue after ignition - at $550^{\circ} \mathrm{C}$. Methodical recommendations contained in the paper (Bedient et al. 1983) were applied during leachate and filtrate testing procedures.

The concentrations of determined chemical parameters of the model solution are presented in Table 2. To compare the artificially prepared solution with the real leachate, the concentrations of pollutants occurring in typical municipal landfill leachate are also shown in Table 2.

\section{Results and discussion}

Figures 1-3 show changes of volume of supplied $\left(\mathrm{V}_{\mathrm{d}}\right)$ and filtered $\left(\mathrm{V}_{\mathrm{f}}\right)$ leachate in dependence on the number of doses of supplied leachate for each column with a specific layer thickness. It appears from the graphs presented in the figures that the higher the intensity of supplied leachate $(\omega)$ the shorter the time intervals between leachate feeding and its outflow, and that differences between the leachate supplied and filtrate grow discernibly. Increase of layer thickness retards filtrate outflow. In layer featuring thickness of $l_{2}=0.6 \mathrm{~m}$, to which filtrate of intensity $\omega_{2}$ was supplied, a slightly greater difference between $\mathrm{V}_{\mathrm{d}}$ and $\mathrm{V}_{\mathrm{f}}$ was noted, compared to the other cases.

This was caused, as the earlier tests have indicated, by slightly lesser compaction of the sand forming this layer (Bedient et al. 1983, Islam and Singhal 2004, Cuevas et al. 2012). Its density was equal to $\rho=1.79 \cdot 10^{3} \mathrm{~kg} / \mathrm{m}^{3}$, whereas, in the other layers it was higher and equal to $\rho_{a v}=1.83 \cdot 10^{3} \pm$ $0.018 \mathrm{~kg} / \mathrm{m}^{3}$.

Based on known concentrations and volume values $\mathrm{V}_{\mathrm{d}}$ and $\mathrm{V}_{\mathrm{f}}$ the mass of pollutants supplied $\left(m_{d}\right)$ and flowing from the layer $\left(m_{f}\right)$ was calculated for each test stage. To calculate $m_{d}$ and $m_{f}$ average concentration values of pollutants supplied in particular test series were applied for constant filter bed thickness $l$. Consequently, the mass of pollutants in doses of supplied leachate was slightly different in each test series. The charge of considered pollutants in particular experiments was given based on the total solids parameter (Figs. 4-6). Graphs in Figures 4-6 illustrate mass of pollutants contained in the filtrate in dependence on the number of supplied leachate doses for all three test series. To each layer of a given series ( $l=$ const.) various volumes of leachate were supplied $\left(\mathrm{V}_{1}, \mathrm{~V}_{2}\right.$ or $\left.\mathrm{V}_{3}\right)$, therefore, intensity differed $\left(\omega_{1}, \omega_{2}\right.$ or $\left.\omega_{3}\right)$ and the mass of supplied pollutants differed $\left(m_{d}\right)$. The amount of pollutants mass in the filtrate depends on the layer thickness and intensity of leachate supplied.

Table 2. Chemical composition of the model solution and leachates occurring in the Middle Pomeranian (Poland) landfills (Szymański and Nowak 2012)

\begin{tabular}{|c|c|c|c|c|c|}
\hline \multirow{2}{*}{ Parameters } & \multirow{2}{*}{ Unit of measure } & \multicolumn{2}{|c|}{ Model solution } & \multirow{2}{*}{ Landfill No 1} & \multirow{2}{*}{ Landfill No 2} \\
\hline & & Mean value & Standard deviation & & \\
\hline $\mathrm{pH}$ & & 7.5 & 0.49 & $7.0-8.7$ & 7.52 \\
\hline Total hardness & $\mathrm{gCaCO}_{3} / \mathrm{m}^{3}$ & 18.2 & 1.40 & $5.5-25.0$ & - \\
\hline Calcium & $\mathrm{g} / \mathrm{m}^{3}$ & - & - & $90.0-107.0$ & 184.4 \\
\hline Magnesium & $\mathrm{g} / \mathrm{m}^{3}$ & 20.0 & 4.24 & $8.51-32.0$ & 34.8 \\
\hline Manganese & $\mathrm{g} / \mathrm{m}^{3}$ & Absent & - & $0.1-4.0$ & 1.24 \\
\hline Total iron & $\mathrm{g} / \mathrm{m}^{3}$ & 182.43 & 2.45 & $2.3-100$ & 10.0 \\
\hline Sulfates & $\mathrm{g} / \mathrm{m}^{3}$ & 422.8 & 92.21 & $66.8-460$ & 24.6 \\
\hline Oxidizability & $\mathrm{gO}_{2} / \mathrm{m}^{3}$ & 115.2 & 6.41 & $100-3100$ & 420.0 \\
\hline $\operatorname{COD~} \mathrm{K}_{2} \mathrm{Cr}_{2} \mathrm{O}_{7}$ & $\mathrm{gO}_{2} / \mathrm{m}^{3}$ & 5631.71 & 209.61 & 469-7761 & 3191.0 \\
\hline $\mathrm{BOD}_{5}$ & $\mathrm{gO}_{2} / \mathrm{m}^{3}$ & 810.0 & 189.99 & $188-4000$ & 680.0 \\
\hline Ammonia nitrogen & $\mathrm{g} / \mathrm{m}^{3}$ & 47.43 & 1.31 & $10-452$ & 785.0 \\
\hline Nitrites & $\mathrm{g} / \mathrm{m}^{3}$ & 4.95 & 2.84 & $0.05-0.2$ & 0.09 \\
\hline Nitrates & $\mathrm{g} / \mathrm{m}^{3}$ & 18.71 & 0.90 & $0.1-10.0$ & 0.80 \\
\hline Organic nitrogen & $\mathrm{g} / \mathrm{m}^{3}$ & 80.0 & 0.0 & 32 & - \\
\hline Phosphates & $\mathrm{g} / \mathrm{m}^{3}$ & 100.0 & 14.14 & $0.2-24.0$ & 36.0 \\
\hline Chlorides & $\mathrm{g} / \mathrm{m}^{3}$ & 1206.99 & 31.30 & $58.5-5732$ & 500.0 \\
\hline Total solids & $\mathrm{g} / \mathrm{m}^{3}$ & 3669.23 & 88.64 & $628-21350$ & 5216.0 \\
\hline Residue after ignition & $\mathrm{g} / \mathrm{m}^{3}$ & 2531.33 & 82.82 & 4353-16711 & 2848.0 \\
\hline Ignition losses & $\mathrm{g} / \mathrm{m}^{3}$ & 1137.69 & 33.71 & 2158-4716 & 2368.0 \\
\hline
\end{tabular}




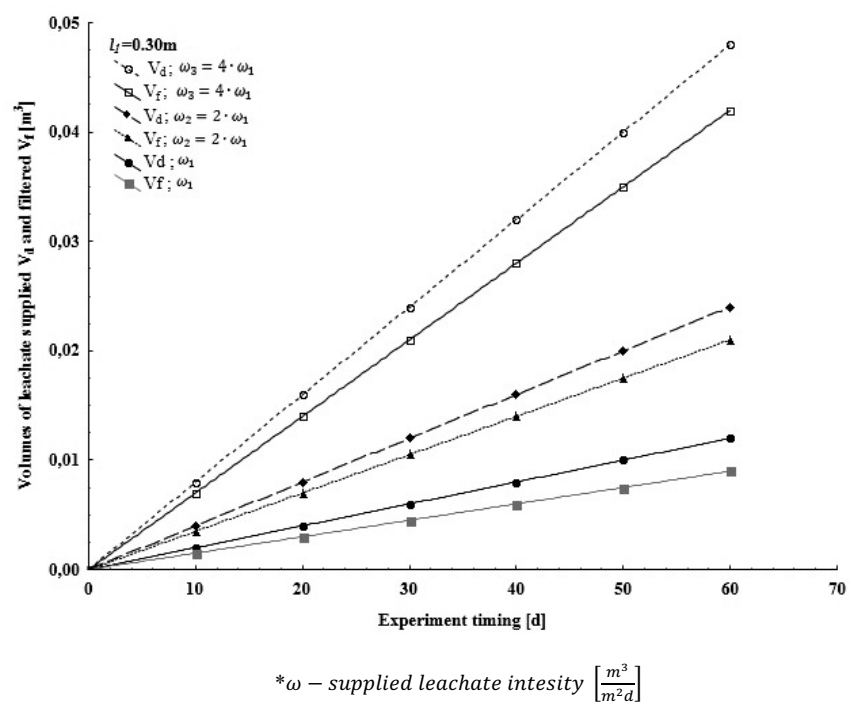

Fig. 1. Filtration test results for model landfill leachates on $0.3 \mathrm{~m}$ thick sand bed

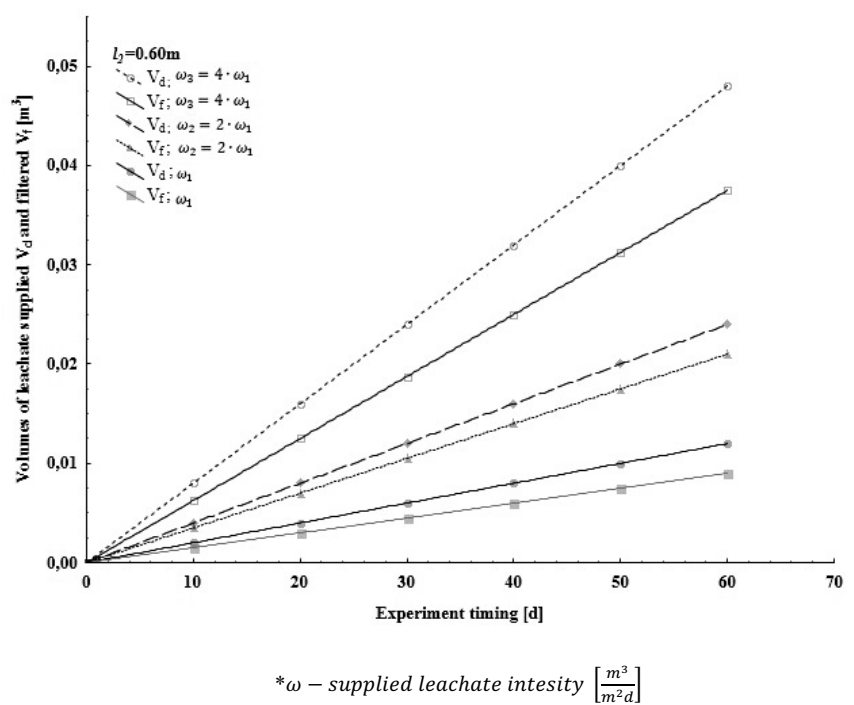

Fig. 2. Filtration test results for model landfill leachates on $0.6 \mathrm{~m}$ thick sand bed

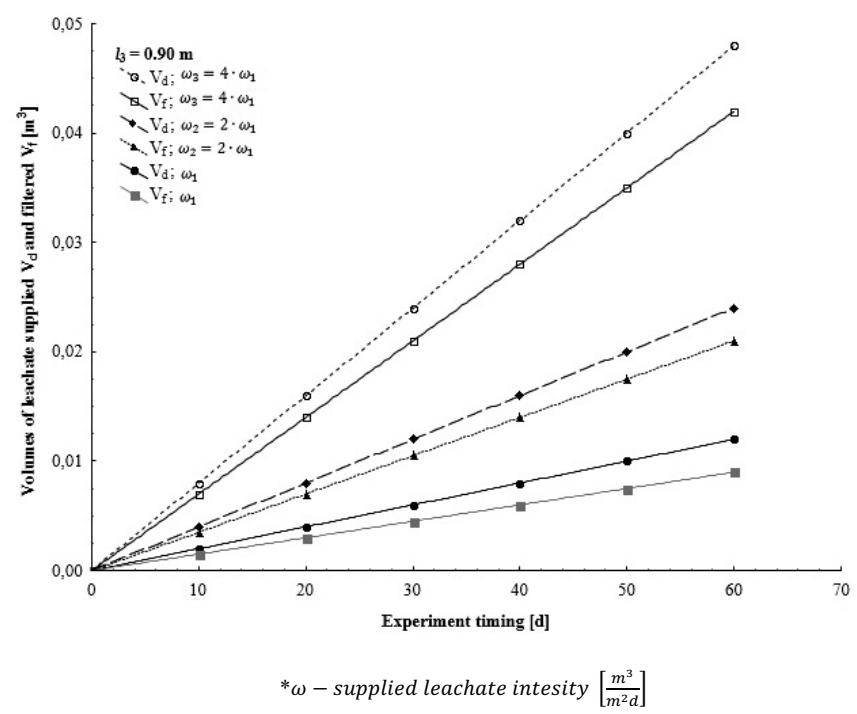

Fig. 3. Filtration test results for model landfill leachates on $0.9 \mathrm{~m}$ thick sand bed

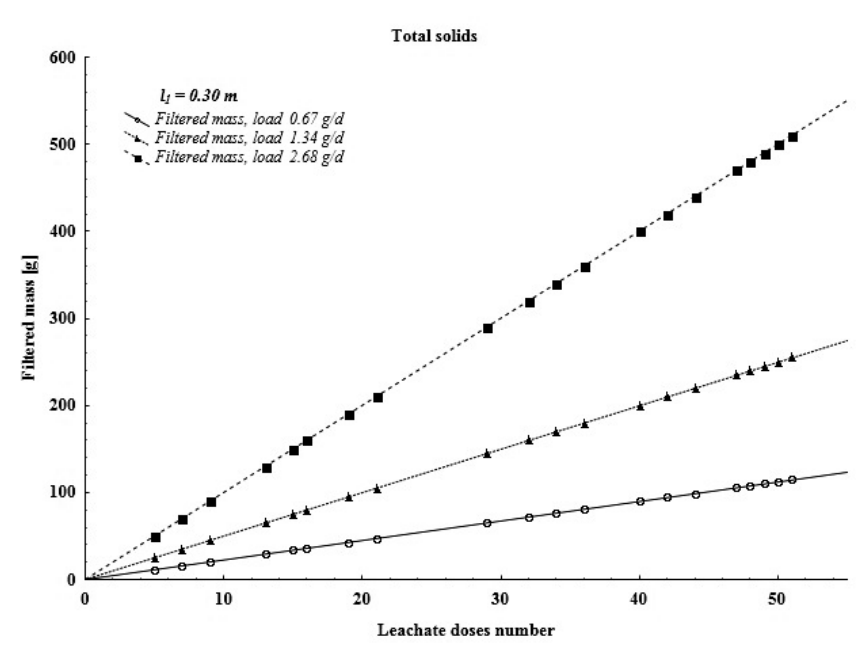

Fig. 4. Change of pollutant load (as total solids) contained in filtrates taken from $0.3 \mathrm{~m}$ thick bed

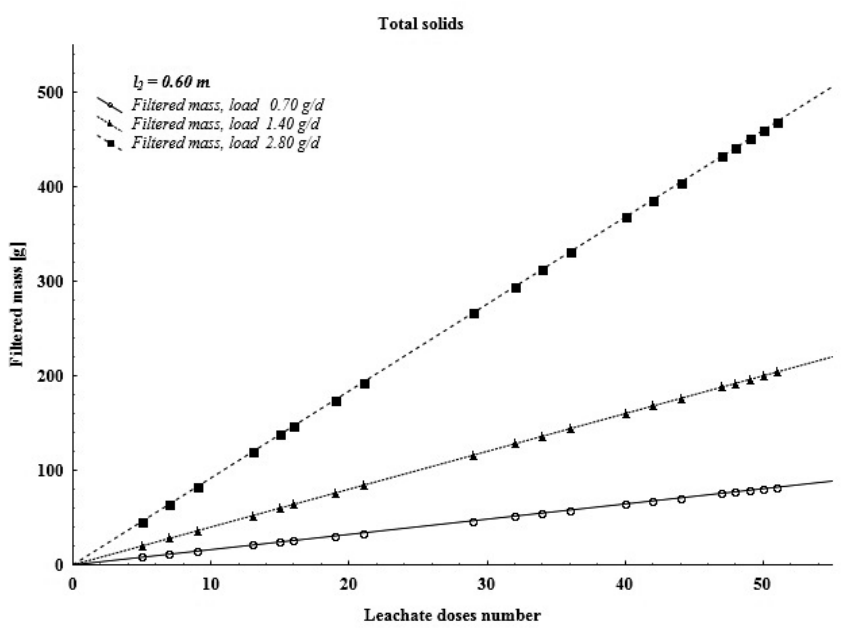

Fig. 5. Change of pollutant load (as total solids) contained in filtrates taken from $0.6 \mathrm{~m}$ thick bed

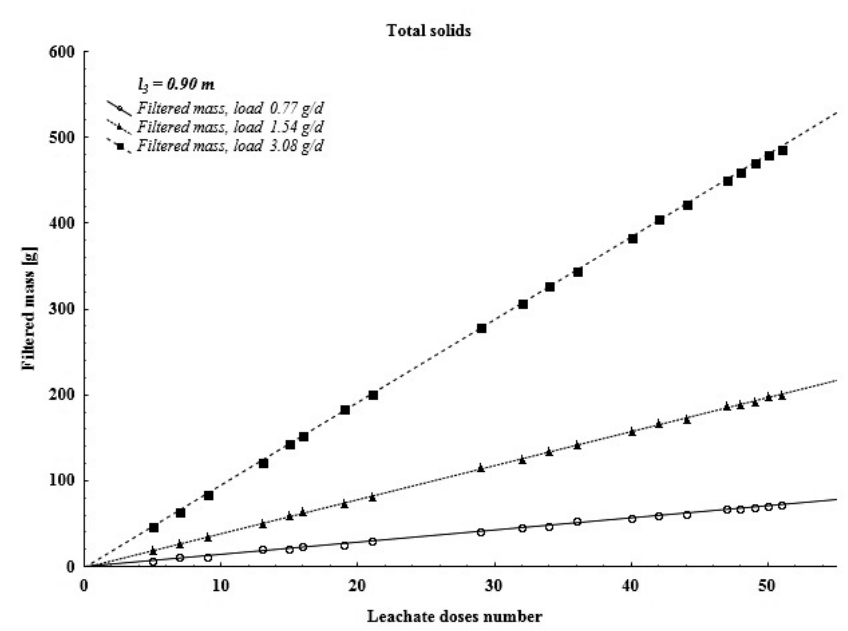

Fig. 6. Change of pollutant load (as total solids) contained in filtrates taken from $0.9 \mathrm{~m}$ thick bed 
Figures 7-9 present a relation between the mass of pollutants contained in leachate and supplied to the filter bed, as well as in the filtrate per unit area $(\mathrm{m} / \mathrm{F})$. Each of three Figures shows the results of three test series performed for different intensities of leachate supplied. It appears from the course of graphs in Figures 7 and 8, that increasing mass of supplied pollutants increases the mass of pollutants contained in the filtrate. This phenomenon is perceptible to a lesser degree in a bed featuring depth of $0.9 \mathrm{~m}$, which can be caused by clogging and also washing out of fine silt fractions.

Comparing results of the three test series it can be noted that as layer thickness increases, the mass of pollutants in filtrate decreases and differences in the course of particular curves obtained for various intensity $\omega$ grow. As far as the total solids are concerned, increase of intensity $\omega$ is accompanied by increase of the filtered mass, which is, beyond any doubt, caused by washing out from the soil of its finer elements (particles and grains) as well as other substances contained in its pores, including organic substances. Share of those substances in the tested medium sand was approx. $2 \%$.

Changes of physical and chemical properties of the soil layer had, beyond any doubt, significant impact on purifying properties of the medium. The relationship between those properties for three test series has been illustrated in Figures 10-12. The Figures show the relative change of the mass of supplied $\left(m_{d}\right)$ and filtered $\left(m_{f}\right)$ pollutant to the mass of pollutants supplied per unit area of layer $\left(m_{d}^{\prime}\right)$ through which they flow as leachate. The relative mass change $\bar{m}$ of a given pollutant was calculated from the following formula:

$$
\bar{m}=\frac{m_{d}-m_{f}}{m_{d}}
$$

The relative mass change may assume values of $\bar{m} £ 1.0$, also negative ones. Values $\bar{m}=1.0$ occur when $m_{f}=0 . \bar{m}=0$ if $m_{f}=m_{d}$, whereas negative values occur if $m_{f}>m_{d}$.

It appears from Figures 10-12 that an increase of $m_{d}$ ' corresponds to a decrease of value $\bar{m}$. Such trend, irrespectively of the intensity of leachate supplies and layer thickness, was found for the total solids. At the initial stage of the experiment decrease of $\bar{m}$ could be noted. A statement seems to be justified that at this test stage processes of washing out of finer soil elements prevail (this is confirmed by negative values $\bar{m}$ of the total solids), which entails increase of leachate flow rate through the sand layer.

The next test phase, in which local increase of the relative mass change can be observed, corresponds to soil compaction (clogging), which results both in decrease of pore volume and leachate flow rate. Due to decrease of porosity and extension of the contact time of leachate with the soil medium, the role of mechanical, physical and chemical purification increases. It manifests itself as increase of $\bar{m}$. As the sorption ability of the soil medium depletes, $\bar{m}$ systematically decrease showing, later on, a trend to assume constant values. In some cases those values asymptotically head towards the same value within a single series scope and sometimes even for all three test series regarding total solids. Value $m_{d}$ ' corresponding to attainment of similar values $\bar{m}$ irrespectively of leachate supply intensity, decreases with decrease of layer thickness $l$. Mass of pollutants supplied to unit area determines the acquisition

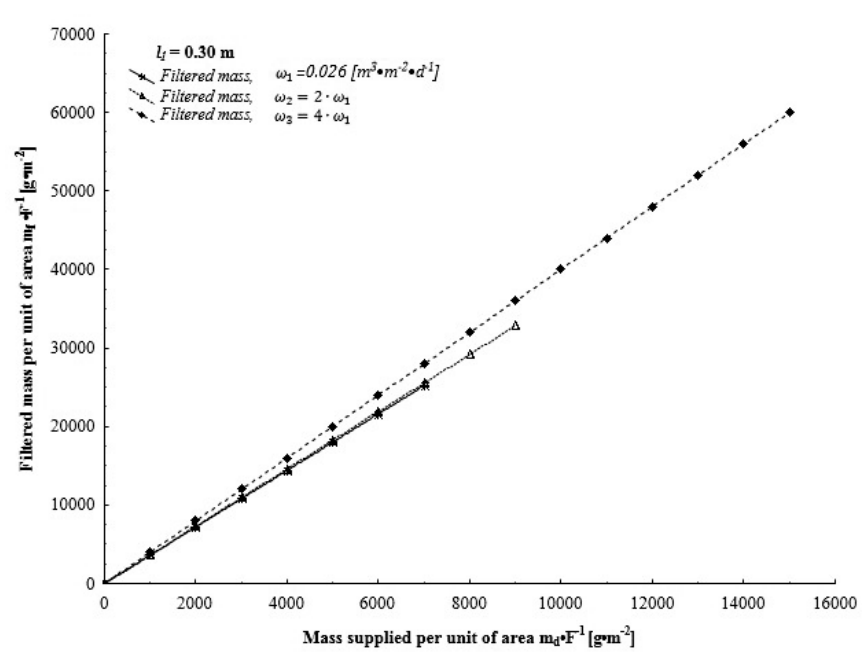

Fig. 7. Relations between mass of pollutants supplied to the filter bed contained in leachate and in filtrate per unit of area

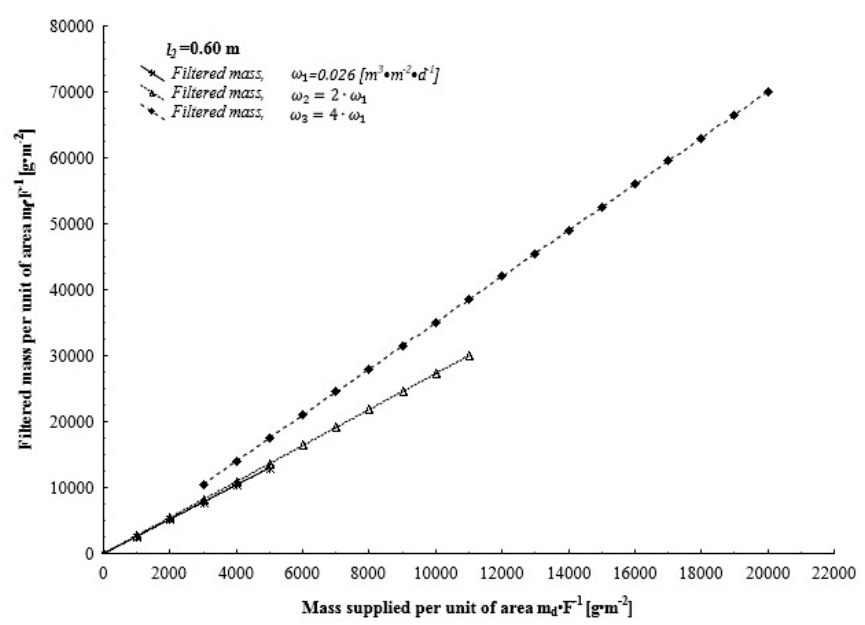

Fig. 8. Relations between mass of pollutants supplied to the filter bed contained in leachate and in filtrate per unit of area

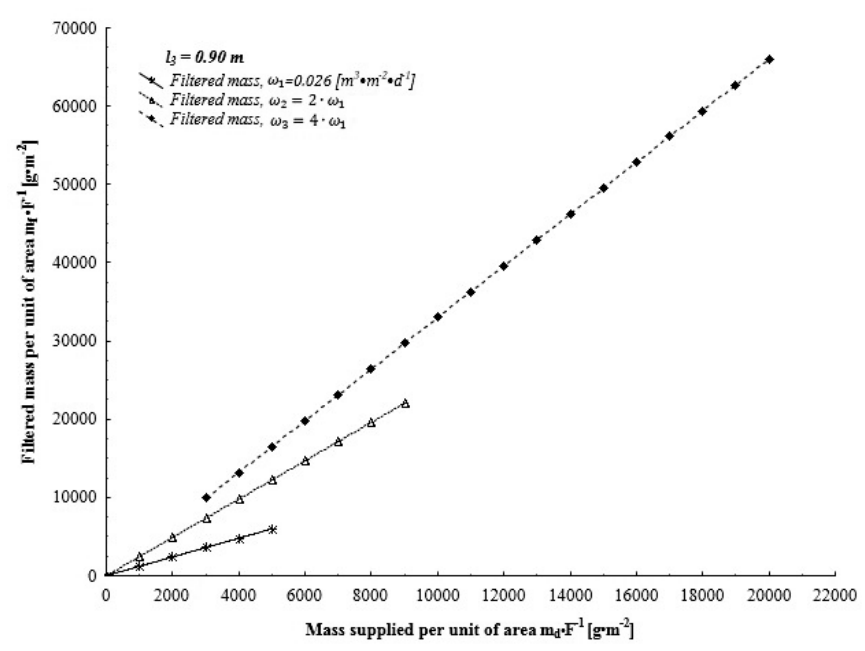

Fig. 9. Relations between mass of pollutants supplied to the filter bed contained in leachate and in filtrate per unit of area 


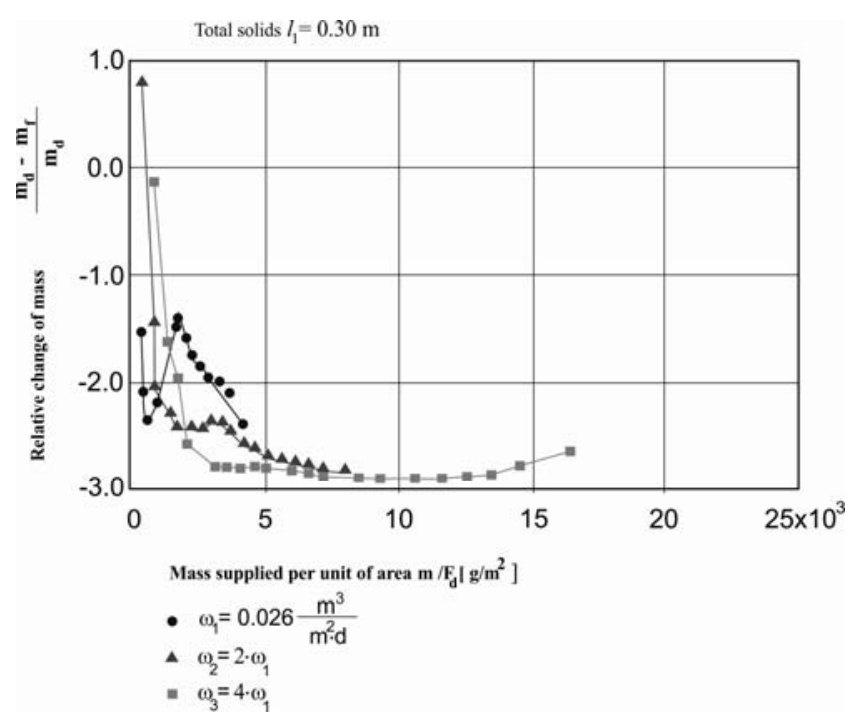

Fig. 10. Relative change of mass of supplied and filtered pollutants compared with the mass of pollutants supplied per unit area of $0.3 \mathrm{~m}$ thick filter layer

of constant physical and mechanical properties by the soil medium. This phenomenon was observed for the majority of pollution indicators analysed (see Table 2). It appears from the tests performed that soil purifying properties are not dependent on intensity of leachates supplied. Attainment of a constant value of this ratio is clearly visible in the highest intensity experiments $\left(\omega_{3}=4 \cdot \omega_{1}\right)$ where the mass of supplied pollutants was the highest. It can be seen that (see Table 3) certain distinct differences occur in the case of ammonium nitrogen compounds, increase concentration of which could be caused by bed oxygen deficit conditions and, in effect, reduction of nitrate compounds to the ammonium form (Brun and Engesgaard 2002, Wisznowski et al. 2006, Lacerda et al. 2014, Zhan et al. 2014). Significant departures from this rule were manifested by chlorides, which were not bound by the soil medium. Chloride anions show high mobility in sandy soil (Cuevas et al. 2012, Zhan et al. 2014).

Based on the test results it can be stated that purification of any leachate infiltrating via a porous medium can be effected mechanically, physically and chemically, not excluding biochemical processes (Brun and Engesgaard 2002, Castrillon et al. 2010, Ghosh et al. 2014).

Gradual reduction of medium porosity has impact, without any doubt, on increase of mechanical purification of infiltrating leachate (Zhang et al. 2016). If such medium contains any organic substances as well as argillaceous minerals, the opportunity for water to evaporate will decrease but at the same time the role of sorption will increase (Thornton et al. 2000, Liu et al. 2010). The model research results clearly indicate that mass of pollutants $\left(m_{f}\right)$ contained in leachate filtered through a porous soil determines intensity of the leachate supplied $(\omega)$ and layer thickness ( $l$ ) (Liu et al. 2010). To define the following function:

$$
m_{f}=m_{f}\left(m_{d}, l, \omega\right)
$$

statistical methods were used and an analytical solution applying multiple regression models was proposed.

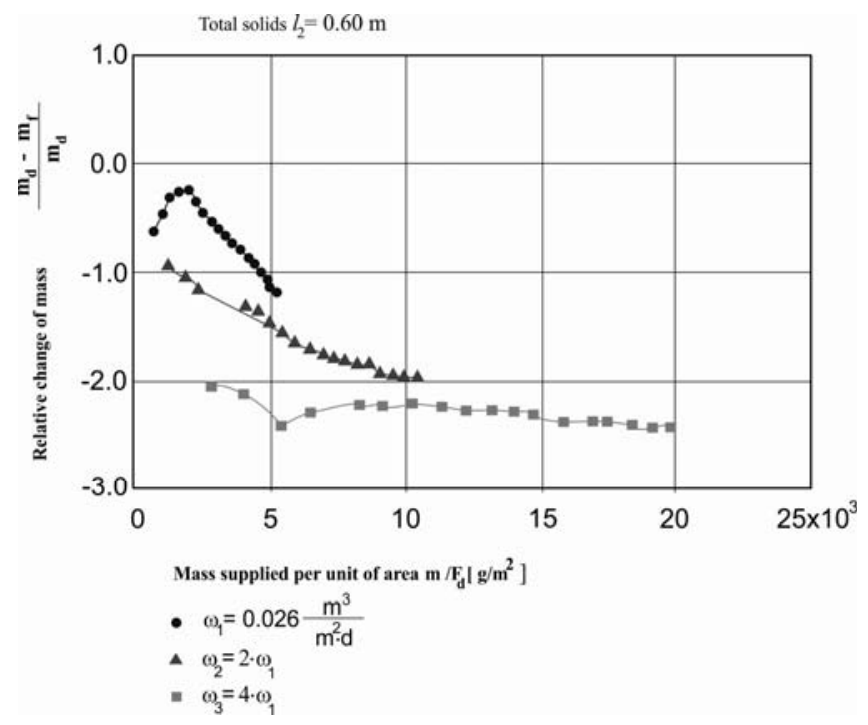

Fig. 11. Relative change of mass of supplied and filtered pollutants compared with the mass of pollutants supplied per unit area of $0.6 \mathrm{~m}$ thick filter layer

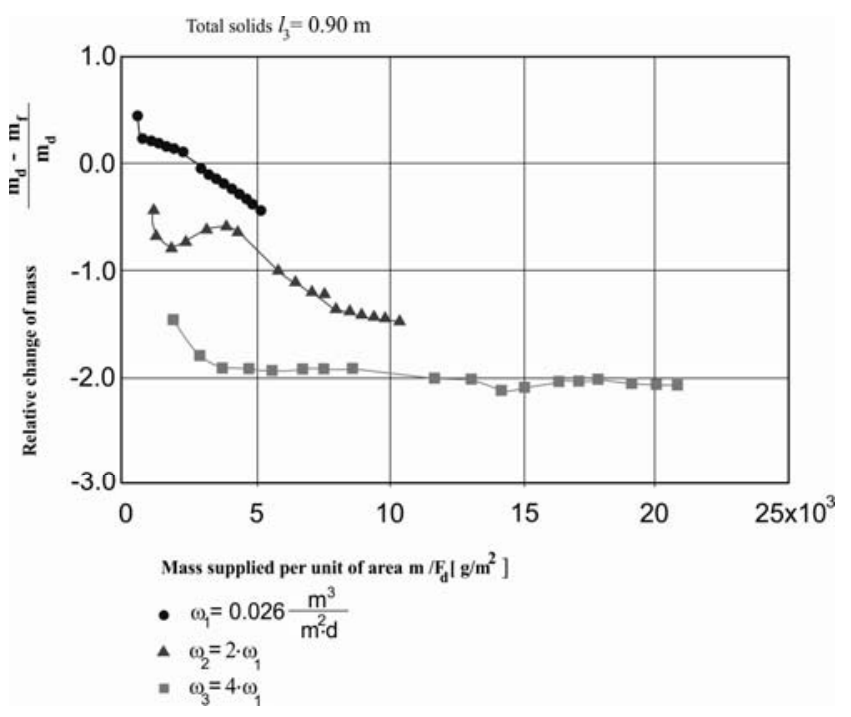

Fig. 12. Relative change of mass of supplied and filtered pollutants compared with the mass of pollutants supplied per unit area of $0.9 \mathrm{~m}$ thick filter layer

Table 3. Asymptotic values of $\Delta m_{f} / \Delta m_{d}$ determined during the tests at intensity. $\omega_{3}=0.104 \mathrm{~m}^{3} / \mathrm{m}^{2} \mathrm{~d}$

\begin{tabular}{|c|c|c|c|}
\hline \multirow{2}{*}{ Pollutant indicator } & \multicolumn{3}{|c|}{ Medium sand layer thickness $I[\mathrm{~m}]$} \\
\cline { 2 - 4 } & $I_{1}=0.3$ & $I_{2}=0.6$ & $I_{3}=0.9$ \\
\hline Total solids & 4.00 & 3.60 & 3.20 \\
\hline Ignition losses & 5.50 & 4.50 & 3.40 \\
\hline $\mathrm{COD} \mathrm{K} \mathrm{Cr}_{2} \mathrm{O}_{7}$ & 0.80 & 0.75 & 0.80 \\
\hline Chlorides & 0.80 & 0.80 & 0.80 \\
\hline Total iron & 0.25 & 0.18 & 0.08 \\
\hline $\begin{array}{c}\text { Ammonium } \\
\text { nitrogen }\end{array}$ & 0.95 & 1.00 & 0.80 \\
\hline Nitrates & 1.80 & 0.80 & 0.40 \\
\hline
\end{tabular}


To describe function (2) the multiple regression function was applied; it subordinates to many tested independent variable mean values of a dependent variable (Luszniewicz and Słaby 2007). To simplify calculations a linear form of the multiple regression function was assumed. Furthermore, an assumption was made that only dependent variable $\left(m_{f}\right)$ is the random variable, whereas the independent variables $\left(m_{d}, l, \omega\right)$ are not treated as random variables but their values are known (such as were assumed in the research work). Such assumption requires introduction of a random element into the model. Assuming that the random element has its expected value equal to zero, a function subordinating to the independent variable values the expected dependent variable values, is obtained.

Assuming for given pollutant indicator a linear relationship between $m_{f}$ and $m_{d}, l$ and $\omega$ taking into account the random element, it can be written in the following form:

$$
\begin{gathered}
\left(m_{f}\right)_{t}=b_{1}\left(m_{d}\right)_{t}+b_{2}(l)_{t}+b_{3}(\omega)_{t}+b_{4}+\varepsilon_{t} \\
(t=1,2,2 \ldots ., 9),
\end{gathered}
$$

where $\varepsilon_{t}$ has normal distribution of unknown variance $\sigma^{2}$.

Assuming a positive variable $\mathrm{x}=1 \mathrm{v}$ at the free element, the following relation (3) can be written in matrix form:

$$
y=X b+\varepsilon
$$

where relevant vectors $y, b$ and $\varepsilon$ as well as matrix $\mathrm{X}$ are as follows:

$$
y=\left[\begin{array}{l}
\left(m_{f}^{\prime}\right)_{11} \\
\left(m_{f}^{\prime}\right)_{12} \\
\left(m_{f}^{\prime}\right)_{13} \\
\left(m_{f}^{\prime}\right)_{21} \\
\left(m_{f}^{\prime}\right)_{22} \\
\left(m_{f}^{\prime}\right)_{23} \\
\left(m_{f}^{\prime}\right)_{31} \\
\left(m_{f}^{\prime}\right)_{32} \\
\left(m_{f}^{\prime}\right)_{33}
\end{array}\right], b=\left[\begin{array}{l}
b_{1} \\
b_{2} \\
b_{3} \\
b_{4}
\end{array}\right], \varepsilon=\left[\begin{array}{l}
1 \\
2 \\
3 \\
4 \\
5 \\
6 \\
7 \\
8 \\
9
\end{array}\right] . X=\left[\begin{array}{llll}
\left(m_{d}^{\prime}\right)_{11} & l_{1} & \omega_{1} & 1 \\
\left(m_{d}^{\prime}\right)_{12} & l_{1} & \omega_{2} & 1 \\
\left(m_{d}^{\prime}\right)_{13} & l_{1} & \omega_{3} & 1 \\
\left(m_{d}^{\prime}\right)_{21} & l_{2} & \omega_{1} & 1 \\
\left(m_{d}^{\prime}\right)_{22} & l_{2} & \omega_{2} & 1 \\
\left(m_{d}^{\prime}\right)_{23} & l_{2} & \omega_{3} & 1 \\
\left(m_{d}^{\prime}\right)_{31} & l_{3} & \omega_{1} & 1 \\
\left(m_{d}^{\prime}\right)_{32} & l_{3} & \omega_{2} & 1 \\
\left(m_{d}^{\prime}\right)_{33} & l_{3} & \omega_{3} & 1
\end{array}\right]
$$

Values $\left(m_{f}^{\prime}\right)_{i j}$ and $\left(m_{d}^{\prime}\right)_{i j}$, where $\mathrm{i}=1,2,3$ corresponds to layer thickness $l_{\mathrm{i}}\left(l_{1}=0.3 \mathrm{~m} ; l_{2}=0.6 \mathrm{~m} ; l_{3}=0.9 \mathrm{~m}\right)$ and $j=1,2$, 3 corresponds to intensity $\omega_{j}\left(\omega_{1}=0.026 \mathrm{~m}^{3} / \mathrm{m}^{2} \mathrm{~d} ; \omega_{2}=2 \cdot \omega_{1}\right.$; $\left.\omega_{3}=4 \cdot \omega_{1}\right)$, were calculated as arithmetic means of all results obtained in a given test. It should be noted that values $m_{f}^{\prime}$ and $m_{d}$ 'were calculated for layer's unit area.

In accordance with the assumed model, vector $b$ of the parameters was estimated by:

$$
b=\left(X^{T} \cdot X\right)^{-1} X^{T} \cdot y
$$

Furthermore, the multiple correlation factor $\mathrm{R}$ measuring the degree of correlation of variable from independent variables $m_{d}{ }^{\prime}, l, \omega$ was calculated. In the matrix form it is expressed by the following formula:

$$
R=\sqrt{1-\frac{y^{T} \cdot y-b^{T} \cdot X^{T} \cdot y}{y^{T} \cdot y-\frac{1}{n}\left(1^{T} \cdot y\right)^{2}}}
$$

where $1^{\mathrm{T}}$ is, in the considered case, a nine-dimensional row vector of unities. Factor $\mathrm{R}$ is a measure of linear model matching with empirical data. The closer the value of factor $\mathrm{R}$ is to unity, the better is the model match.

Calculations of the regression parameters and the multiple correlation coefficient were performed using computer package STATISTICA PL. The calculation results obtained for particular pollutant indicators are set out in Table 4.

\section{Conclusions}

Flow of leachate through a soil layer causes a change in physical and chemical properties of porous medium. This pertains, first and foremost, to porosity (reduction of layer height was observed), granularity (soil particles and fine grains were washed out) and permeability (liquid flow rate decreased slightly) (Nayak et al. 2007, Zhang et al. 2016). Changes of those parameters were particularly evident during the first test stage. Intensity of those changes depended on the volume of individually supplied leachate doses and soil layer

Table 4. Linear multiple regression functions for leachates supplied to the filter bed

\begin{tabular}{|c|c|c|}
\hline Pollutant indicator & $\begin{array}{c}\text { Regression function } \\
m_{f}^{\prime}=m_{f}^{\prime}\left(m_{d^{\prime}} l, \omega\right)\end{array}$ & $\begin{array}{c}\text { Multiple correlation } \\
\text { coefficient (R) }\end{array}$ \\
\hline Total solids & $m_{f}^{\prime}=2.94 m_{d}^{\prime}-8,536.81 \quad l+94,096.20 \omega-343.76$ & 0.9996 \\
\hline Ignition losses & $m_{f}^{\prime}=2.98 m_{d}^{\prime}-6,241.35 \quad l+55,879.35 \omega+1,479.78$ & 0.9976 \\
\hline COD $\mathrm{Cr}_{2} \mathrm{O}_{7}$ & $m_{f}^{\prime}=0.54 m_{d}^{\prime}+291.75 \quad l+25,485.90 \omega-2,162.76$ & 0.9957 \\
\hline Chlorides & $m_{f}^{\prime}=0.19 m_{d}^{\prime}+1,473.61 \quad l+26,139.38 \omega-1,081.36$ & 0.9879 \\
\hline Total iron & $m_{f}^{\prime}=-0.02 m_{d}^{\prime}-19.54 \quad l+434.80 \omega+19.13$ & 0.9887 \\
\hline Ammonium nitrogen & $m_{f}^{\prime}=0.92 m_{d}^{\prime}-42.51 \quad l-13.31 \omega+4.96$ & 0.9978 \\
\hline Nitrates & $m_{f}^{\prime}=-0.58 m_{d}^{\prime}+9.09 \quad l+451.37 \omega-5.01$ & 0.9785 \\
\hline
\end{tabular}

Legend:

$m_{f}^{\prime}-$ mass of the filtered pollutant per unit of area $\left[\mathrm{g} / \mathrm{m}^{2}\right]$.

$m_{d}^{\prime}-$ mass of pollutant supplied to the soil per unit of area $\left[\mathrm{g} / \mathrm{m}^{2}\right]$.

$l^{d}$ - layer thickness [m].

$\omega$ - leachate supply intensity $\left[\mathrm{m}^{3} / \mathrm{m}^{2} \mathrm{~d}\right]$. 
thickness. This means that smaller leachate doses and greater layer depth result in slower ground particle compaction and washing out processes. As subsequent doses of the leachate were supplied, those processes gradually faded out which indicated stabilisation of the physical and chemical properties of the soil layer. The higher the intensity of leachate supplies and the smaller the layer thickness, the smaller was the volume of discharged leachate.

Determined regression functions allow for both qualitative and quantitative estimation of impact of the analysed independent variables $\left(m_{d}^{\prime}, l, \omega\right)$ on the values of pollutant masses flowing out from the medium sand layer. The values of the correlation coefficient close to unity indicate high correlation, i.e. good compatibility with the linear model of empirical values of variable $m_{f}^{\prime}$ Comparing regression functions of particular pollutant indicators (see Table 3) one can clearly see a resemblance between the total solids and ignition losses as well as between COD and chlorides. In the case of ammonium nitrogen, the influence of $m_{d}^{\prime}, l$ and $\omega$ is inversely proportional. This means that those factors, which result in an increase of a single pollutant indicator, cause reduction of value $m_{f}^{\prime}$ of another indicator.

Generally, it can be pointed out that the adopted multiple regression method can be successfully applied for estimation of the mass of pollutants flowing from not entirely saturated porous medium for values of $m_{d}, l$ and $\omega$ that fall within the range of the values used in the model research work. Extrapolation, particularly in the case where $m_{d} \rightarrow 0, l \rightarrow 0$ and $\omega \rightarrow 0$, does not guarantee acquisition of correct values.

\section{References}

Abdelaal, F.B., Rowe, R.K. \& Islam, M.Z. (2014). Effect of leachate composition on the long-term performance of a HDPE geomembrane, Geotextiles and Geomembranes, 42, pp. 348-362.

Bedient, P., Springer, N., Baca, E., Bouvette, T., Hutchins, S. \& Tomson, M. (1983). Ground-water transport from wastewater infiltration, Journal of Environmental Engineering, 109, 2, pp. 485-501.

Brun, A. \& Engesgaard, P. (2002). Modelling of transport and biogeochemical processes in pollution plumes: literature review and model development, Journal of Hydrology, 256, pp. 211-227.

Castrillón, L., Fernández-Nava, Y., Ulmanu, M., Anger, I. \& Marañón, E. (2010). Physico-chemical and biological treatment of MSW landfill leachate, Waste Management, 30, pp. 228-235.

Cooke, A.J., Rowe, R.K. \& Rittmann, B.E. (2005). Modelling species fate and porous media effects for landfill leachate flow, Canadian Geotechnical Journal, 42, pp. 1116-1132.

Cuevas, J., Ruiz, A. I., de Soto, I. S., Sevilla, T., Procopio, J. R., Da Silva, P., Gismera, M. J., Regadío, M., Sánchez Jiménez, N., Rodríguez Rastrero, M. \& Leguey, S. (2012). The performance of natural clay as a barrier to the diffusion of municipal solid waste landfill leachates, Journal of Environmental Management, 95, pp. S175-S181.

Den Boer, E., Jędrczak, A., Kowalski, Z., Kulczycka, J. \& Szpadt, R. (2010). A review of municipal solid waste composition and quantities in Poland, Waste Management, 30, pp. 369-377.

Ghosh, P., Swati, \& Thakur, I.S. (2014). Enhanced removal of COD and color from landfill leachate in a sequential bioreactor, Bioresource Technology, 170, pp. 10-19.

Ghosh, S., Mukherjee, S., Al-Hamdan, A.Z. \& Reddy, K.R. (2013). Efficacy of fine-grained soil as landfill liner material for containment of chrome tannery sludge, Geotechnical and Geological Engineering, 31, pp. 493-500.
Islam, J. \& Singhal, N. (2004). A laboratory study of landfill leachate transport in soils, Water Research, 38, pp. 2035-2042.

Janowska, B. \& Szymański, K. (2009). Transformation of selected trace elements during the composting process of sewage sludge and municipal solid waste, Fresenius Environmental Bulletin, 18, 7, pp. 1110-1117.

Kjeldsen, P., Barlaz, M.A., Rooker, A. P., Baun, A., Ledin, A. \& Christensen, T.H. (2002). Present and Long-Term Composition of MSW Landfill Leachate: A Review, Environmental Science and Technology, 32, 4, pp. 297-336.

Koda, E., Wiencław, E. \& Martelli, L. (2009). Transport modelling and monitoring research use for efficiency assessment of vertical barrier surrounding old sanitary landfill, Annals of Warsaw University of Life Sciences - SGGW Land Reclamation, 41, pp. 41-48.

Lacerda, C.V., Ritter, E., da Costa Pires, J.A. \& de Castro, J.A. (2014). Migration of inorganic ions from the leachate of the Rio das Ostras landfill: A comparison of three different configurations of protective barriers, Waste Management, 34, pp. 2285-2291.

Lagaly, G., Ogawa, M. \& Dekany, I. (2006). Clay mineral - organic interaction. In: Handbook of clay science, Bergaya, F., Theng, B.K.G. \& Lagaly, G. (Eds.), Elsevier, Amsterdam, pp. 309-377.

Li, Y., Li, J., Chen, S. \& Diao, W. (2012). Establishing indices for groundwater contamination risk assessment in the vicinity of hazardous waste landfills in China, Environmental Pollution, 165, pp. 77-90.

Liu, Z.J., Li, X.K. \& Tanga, L.Q. (2010). The numerical simulation of coupling behavior of soil with chemical pollutant effects, AIP Conference Proceedings, 1233, 1, pp. 690-695.

Luszniewicz, A. \& Słaby, T. (2009). Statistics with computer package of STATISTICA PL. Theory and Applications. CH Beck, Warszawa 2009. (in Polish)

Melnyk, A., Kuklińska, K., Wolska, L. \& Namieśnik, J. (2014). Chemical pollution and toxicity of water samples from stream receiving leachate from controlled municipal solid waste (MSW) landfill, Environmental Research, 135, pp. 253-261.

Nayak, S., Sunil, B.M. \& Shrihari, S. (2007). Hydraulic and compaction characteristics of leachate-contaminated lateritic soil, Engineering Geology, 94, 3-4, 2, pp. 137-144.

Pieczykolan, B., Płonka, I., Barbusiński, K. \& Amalio-Kosel, M. (2013). Comparison of landfill leachate treatment efficiency using the advanced oxidation processes, Archives of Environmental Protection, 39, 2, pp. 107-115.

Regadío, M., Ruiz, A.I., de Soto, I.S., Rodriguez Rastrero, M., Sánchez, N., Gismera, M.J., Sevilla, M.T., da Silva, P., Rodríguez Procopio, J. \& Cuevas, J. (2012). Pollution profiles and physicochemical parameters in old uncontrolled landfills, Waste Management, 32, pp. 482-497.

Renou, S., Givaudan, J.G., Poulain, S., Dirassouyan, F. \& Moulin, P. (2008). Landfill leachate treatment: Review and opportunity, Journal of Hazardous Materials, 150, pp. 468-493.

Reyes-López, J.A., Ramírez-Hernández, J., Lázaro-Mancilla, O., Carreón-Diazcontia, C. \& Martín-Loeches Garrido, M. (2008). Assessment of groundwater contamination by landfill leachate: A case in México, Waste Management, 28, pp. S33-S39.

Rosqvist, H. \& Destouni, G. (2000). Solute transport through preferential pathways in municipal solid waste, Journal of Contaminant Hydrology, 46, pp. 39-60.

Schiopu, A.M. \& Gavrilescu, M. (2010). Options for the treatment and management of municipal landfill leachate: common and specific, Clean: Soil, Air, Water, 38, 12, pp. 1101-1110.

Siebielska, I. (2014). Comparison of changes in selected polycyclic aromatic hydrocarbons concentration during the composting and anaerobic digestion process of municipal waste and sewage sludge mixtures, Water Science and Technology, 70, 1, pp. 1617-1624. 
Siebielska, I. \& Sidełko, R. (2015). Polychlorinated biphenyl concentration changes in sewage sludge and organic municipal waste mixtures during composting and anaerobic digestion, Chemosphere, 126, pp. 88-95.

Suchowska-Kisielewicz, M. \& Jędrczak, A. (2008). The chemical composition of leachate from municipal solid and mechanical biological treatment wastes. In: Management of pollutant emission from landfills and sludge, Pawłowska, M. \& Pawłowski, L. (Eds.), Taylor \& Francis, London, pp. 177-186.

Szymański, K. \& Nowak, R. (2012). Transformations of leachate as a result of technical treatment at municipal waste landfills, Annual Set The Environmental Protection, 14, pp. 337-350. (in Polish)

Szymański, K., Sidełko, R., Janowska, B. \& Siebielska I. (2007). Monitoring of waste landfills, Zeszyty Naukowe Wydziatu Budownictwa i Inżynierii Środowiska, 23, pp. 75-133. (in Polish).

Tałałaj, I.A. \& Dzienis, L. (2007). Influence of leachate on quality of underground waters, Polish Journal of Environmental Studies, 16, 1, pp. 139-144.

Szymański, K. \& Siebielska, I. (2000). Evaluation of groundwater pollution: analytical problems, Ochrona Środowiska, 76, 1, pp. 15-18. (in Polish)

Thornton, S.F., Bright, M.I., Lerner, D.N. \& Tellam, J.H. (2000). Attenuation of landfill leachate by UK Triassic sandstone aquifer materials. 2. Sorption and degradation of organic pollutants in laboratory columns, Journal of Contaminant Hydrology, 43, pp. 355-383.

Tonjes, D.J. (2013). Classification Methodology for Landfill Leachates, Journal of Environmental Engineering, 139, 8, pp. 1119-1122.

Wiszniowski, J., Robert, D., Surmacz-Górska, J., Miksch, K. \& Weber, J.V. (2006). Landfill leachate treatment methods: A review, Environmental Chemistry Letters, 4, pp. 51-61.

Varank, G., Demir, A., Top, S., Sekman, E., Akkaya, E., Yetilmezsoy, K. \& Bilgili, M.S. (2011). Migration behavior of landfill leachate contaminants through alternative composite lines, Science of the Total Environment, 409, pp. 3183-3196.

Zhan, T.L.T., Guan, C., Xie, H.J. \& Chen, Y.M. (2014). Vertical migration of leachate pollutants in clayey soils beneath an uncontrolled an landfill at Huainan, China: A field and theoretical investigation, Science of the Total Environment, 470-471, pp. 290-298.

Zhang, H., Yang, B., Zhang, G. \& Zhang, X. (2016). Sewage sludge as barrier material for heavy metals in waste landfill, Archives of Environmental Protection, 42, 2, pp. 52-58.

Zhu, N., Ku, T.T., Li, G. \& Sang, N. (2013). Evaluating biotoxicity variations of landfill leachate as penetrating through the soil column, Waste Management, 33, pp. 1750-1757.

\section{Migracja zanieczyszczeń w porowatym ośrodku gruntowym}

Streszczenie: Odcieki składowiskowe stanowią potencjalne zanieczyszczenie wód gruntowych. Podłoże składowiska odpadów komunalnych może służyć do usuwania zanieczyszczeń zawartych w odciekach. Badania modelowe przeprowadzono z wykorzystaniem złoża piaskowego i sztucznie przygotowanych odcieków. Skuteczność filtracji złoża o określonej miąższości oceniano na podstawie zawartości suchej pozostałości. Wyniki przeprowadzonych badań modelowych wykazały, że o masie zanieczyszczeń zawartych w odcieku, filtrowanym przez warstwę gruntu porowatego $\left(m_{f}\right)$ decyduje masa doprowadzonych zanieczyszczeń $\left(m_{d}\right)$, intensywność doprowadzonego odcieku $(\omega)$ oraz miąższość warstwy $(l)$. Wyznaczone funkcje regresji wykazują, zgodność z liniowym modelem empirycznych wartości zmiennej $m_{f}^{\prime}$. Wyznaczone funkcje regresji pozwalają na oszacowanie jakościowego i ilościowego wpływu analizowanych zmiennych niezależnych $\left(m_{d}^{\prime}, l, \omega\right)$ na wartości masy zanieczyszczeń wypływających z warstwy piasku średniego. Wyniki tych badań mogą służyć do prognozowania stopnia zanieczyszczenia gruntu oraz wód podziemnych zalegających w strefie potencjalnego oddziaływania składowiska odpadów komunalnych. 